Conclusions: Most of this RA patients cohort with dry syndrome were considered as "high probability SS", however only a small percentage (12\%-23\%) fulfilled the classification criteria. This can be explained by the low rate of specific antibodies $(6 \%)$, and by the poor performance of some tests included in the criteria.

Disclosure of Interest: None declared

DOI: 10.1136/annrheumdis-2018-eular.6977

\section{AB0565 1 CHANGES IN HEALTH RELATED QUALITY OF LIFE IN RENAISSANCE COHORT OF RUSSIAN PATIENTS WITH SYSTEMIC LUPUS ERYTHEMATOSUS}

E. Aseeva ${ }^{1}$, L. Vorobyova ${ }^{1}$, S. Soloviev ${ }^{1}$, G. Koilubaeva ${ }^{2}$, S. Glukhova ${ }^{1} .{ }^{1}$ Intensive care department, V.A. Nasonova Research Institute of Rheumatology, Moscow, Russian Federation; ${ }^{2}$ rheumatology department, National Center of Cardiology and Internal Medicine named after Academician M. Mirrahimov, Bishkek, Kyrgyztan

Background: The Lupus Quality of Life (LupusQol) is recommended to assess health related quality of life (HRQOL) in systemic lupus erythematosus (SLE). Objectives: The aim of the current study was to assess HRQOL in the first year observation in cohort of patients with systemic lupus erythematosus in Russian Federation (RENAISSANCE)

Methods: The LupusQoL-Russian was administered to a cohort of 128 Russian patients affected with SLE at baseline and follow up visit (in 12 months). Disease activity was evaluated by the SLE disease activity Index-2000 (SLEDAI-2K), and chronic damage by the Systemic Lupus International Collaborating Clinics Damage Index score (SDI) at baseline and follow up visit.

Results: 128 patients (118 (92\%) women; aged 33,02 $\pm 11,04$ years, mean disease duration $100,0 \pm 84,3$ months) were included. At baseline mean SLEDAI $2 \mathrm{~K}$ was $11,2 \pm 8,5$; mean SDI - 1,3 \pm 1.6 , mean daily prednisolone $16,8 \pm 10,9 \mathrm{mg} / \mathrm{day}$ ). For 12 months all patients received standard therapy according SLEDAI $2 \mathrm{~K}$ and their clinical manifestations (prednisolone 100\%, Hydroxychloroquine 72,4\%, Mycophenolate mofetil 25\%, Cyclophosphamide 17\%, Azathioprine 12,5\%, Rituximab $27,3 \%$, belimumab $12,5 \%$ pts). At follow up visit SLEDAI $2 \mathrm{~K}$ score significantly improved up to $6,94 \pm 6,93$ ( $p<0,000029$ ), SDI significantly worse up to 1,7 $\pm 1,9$ ( $p<0,04)$, mean daily prednisolone significantly reduced up to $12,2 \pm 7,3 \mathrm{mg}$ Iday $(\mathrm{p}<0,04)$. All 8 subscales LupusQol showed improvement in the 12 months versus baseline (table 1). Spearmen's correlation with SIEDAI 2K was obtained for Physical health $(r=-0,13)$, Pain $(r=-0,16)$, Planning $(r=-0,21)$, Intimate relationship $(r=-0,17)$ Burden to others $(r=-0,16)$, emotional health $(r=-0,13)$, Body image $(r=-0,21)$.

Abstract AB0565 - Table 1. Changes in LupusQol domains in the first year observation in cohort of patients with systemic lupus erythematosus in Russian Federation (RENAISSANCE)

\begin{tabular}{lccc}
\hline LupusQol domains & $\begin{array}{c}\text { Baseline, mean } \\
\mathbf{S S D}\end{array}$ & $\begin{array}{c}\mathbf{1 2} \text { month, mean } \\
\mathbf{\pm S D}\end{array}$ & $\mathbf{p}$ \\
\hline Physical health & $63,54 \pm 24,03$ & $66,77 \pm 23,09$ & 0004 \\
Pain & $67,42 \pm 25,10$ & $73,62 \pm 24,27$ & 0002 \\
Planning & $61,28 \pm 28,70$ & $67,35 \pm 27,11$ & 0008 \\
Intimate & $64,96 \pm 35,60$ & $72,53 \pm 29,58$ & 0,01 \\
relationship & & & \\
Burden to others & $53,03 \pm 27,78$ & $57,35 \pm 29,62$ & 0,04 \\
Emotional health & $63,16 \pm 22,02$ & $67,65 \pm 19,99$ & 0,01 \\
Body image & $58,32 \pm 29,45$ & $69,49 \pm 23,01$ & 0,0003 \\
Fatigue & $59,88 \pm 24,6$ & $65,68 \pm 22,95$ & 0006 \\
\hline
\end{tabular}

Conclusions: The LupusQoL-Russian is sensitive to change in SLE patients with active SLE. The HRQOL correlated with disease activity, daily prednisolone and biologic.

Disclosure of Interest: None declared

DOI: 10.1136/annrheumdis-2018-eular.1663

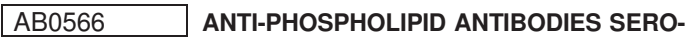 NEGATIVIZATION IN SYSTEMIC LUPUS ERYTHEMATOSUS PATIENTS TREATED WITH BELIMUMAB}

E. Rubini, M. Radin, I. Cecchi, D. Roccatello, S. Sciascia. Università Degli Studi di Torino, Turin, Italy

Background: Belimumab is a monoclonal antibody that blocks the B lymphocyte stimulator, preventing it to bind its receptor on B-lymphocyte's surface, thus avoiding B cell activation. Despite some benefits showed in murine models of anti phospholipid syndrome (APS), ${ }^{1}$ the use of belimumab in this condition needs further investigation.

Objectives: To investigate changes in the antiphospholipid antibodies (aPL) profile in Systemic Lupus Erythematosus (SLE) patients treated with belimumab.
Methods: We retrospectively collected data from patients who attended the $\mathrm{S}$. Giovanni Bosco Hospital, Turin, Italy. Inclusion criteria comprised: a) fulfilled ACR criteria for SLE, b) persistent aPL positivity (confirmed $\geq 3$ occasions over a time $>24$ months before belimumab treatment), c) previous or ongoing belimumab therapy.

Results: This retrospective study included 3 patients with diagnosis of SLE [median age 39(range 33-51), male:female 2:1]. Table 1 resumes the characteris tics of patients. All 3 patients received belimumab because of SLE flares. Before the treatment, Patient\#1, classified as SAPS ${ }^{2}$ presented a persistent triple positivity for lupus anticoagulant (LA), high-titer aCL IgG isotype (>200 GPL) and anti32glicoprotein I antibodies (>50 GPL) (anti- $32 \mathrm{GPI}$ ) IgG isotype. Patient\#2 was persistently positive for IgG aCL and IgM anti- $\beta 2 \mathrm{GPI}$ (both 20-30 GPL and MPL, respectively; cut-off $>7 \mathrm{U}$ ), and had a history of pregnancy morbidity. Patient\#3, classified as SAPS, presented positivity of LA and IgG aCL (10-20 GPL).

After 12 months since belimumab was started, a marked reduction of aPL was noticed, as follows. Patient\#1 became negative for antiß2GPI, while his aCL titre significantly decreased. Anti- $\beta 2 \mathrm{GPI}$ and aCL both turned negative in Patient\#2. After being on belimumab for one year, she planned a pregnancy and she stopped the treatment; after 8 months since suspension, IgG anti $32 \mathrm{GPI}$ antibodies were detectable (cut-off $>3.5 \mathrm{U}$ ). Patient\#3 was persistently negative for aCL while being on belimumab. When he discontinued the therapy, IgG aCL antibodies returned positive. Figure 1 illustrates aPL titres of the 3 patients in relationship with belimumab therapy

Abstract AB0566 - Table 1. Characteristics of the patients included in the study

\begin{tabular}{|c|c|c|c|c|c|c|}
\hline & Sex & Age & Diagnosis & $\begin{array}{l}\text { Associated } \\
\text { Autoimmune } \\
\text { Disease }\end{array}$ & $\begin{array}{c}\text { aPL } \\
\text { positivity }\end{array}$ & Clinical Events \\
\hline Patient\#1 & $M$ & 51 & SAPS & SLE & $\begin{array}{c}\mathrm{LA}, \mathrm{aCL} \\
\text { IgG, anti- } \beta \\
2 \mathrm{GPI} \lg \mathrm{G}\end{array}$ & $\begin{array}{l}\text { Sub-popliteal } \\
\text { arteriopathy }\end{array}$ \\
\hline Patient\#2 & $\mathrm{F}$ & 33 & aPL carrier & SLE & $\begin{array}{l}\text { aCL IgG, } \\
\text { anti- } \beta 2 \mathrm{GPI} \\
\lg \mathrm{M}\end{array}$ & $\begin{array}{l}2 \text { miscarriages } \\
<10 \text { th week of } \\
\text { gestation }\end{array}$ \\
\hline Patient\#3 & M & 39 & SAPS & SLE & $\begin{array}{l}\mathrm{LA} \text {, anti- } \beta \\
2 \mathrm{GPI} \lg \mathrm{G}\end{array}$ & $\begin{array}{c}3 \text { episodes of TVP } \\
\text { severe } \\
\text { thrombocytopenia }\end{array}$ \\
\hline
\end{tabular}
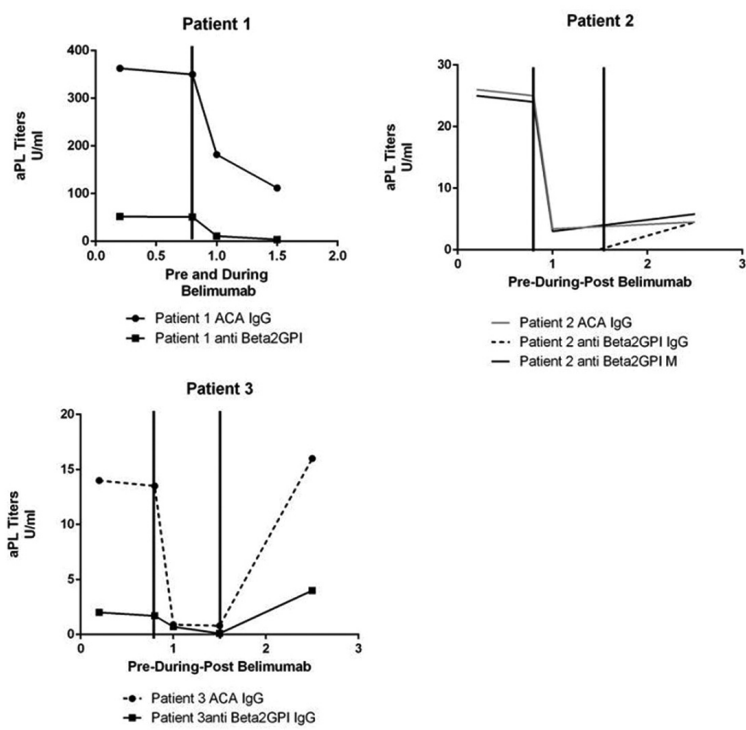

-... Patient 2 anti

Abstract AB0566 - Figure 1. aPL titres of the three patients in relationship with belimumab therapy

Conclusions: Despite its limitations, this pilot study is the first report of aPL negativization after starting therapy with belimumab. The clinical relevance of these findings should be investigated in prospective multicenter studies.

\section{REFERENCES:}

[1] Khattri S, Zandman-Goddard G, Peeva E. B-cell directed therapies in antiphospholipid antibody syndrome-new directions based on murine and human data. Autoimmun Rev 2012;11:717-22.

[2] Miyakis S, Lockshin MD, Atsumi T, et al. International consensus statement on an update of the classification criteria for definite antiphospholipid syndrome (APS). J Thromb Haemost 2006;4:295-306. 